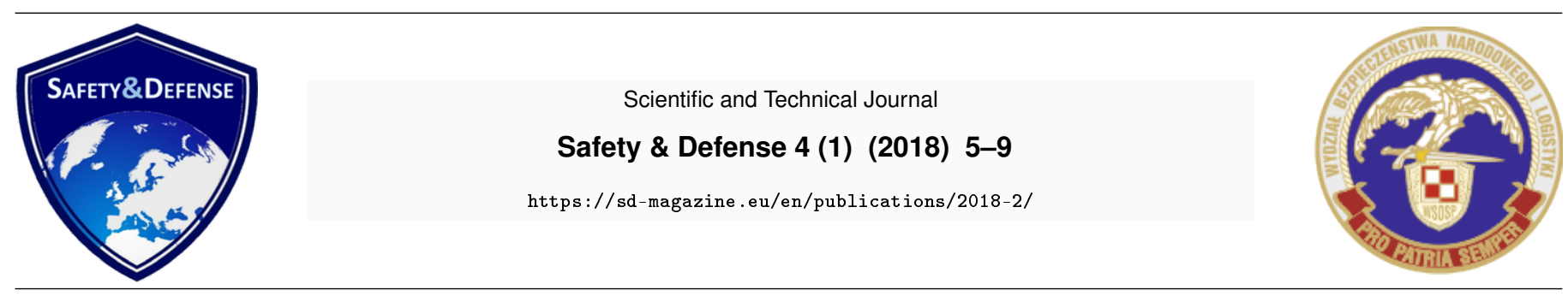

\title{
Mustafa Kemal usage of Mission Command Principles in the Gallipoli Campaign
}

\author{
Meu-Chun Wang* \\ ADA Battery XO, Taiwan Air Force, Taiwan
}

\begin{abstract}
The main goal of the paper is to present the leadership of Mustafa Kemal (also known as Mustafa Kemal Atatürk) during the Gallipoli Campaign in the context of mission command principles as defined by the U.S. Army Doctrine (2014). After itemizing the six mission command principles, the paper provides a brief overview of the Gallipoli Campaign, which serves as a context for further analysis of Mustafa Kemal's leadership during the campaign. Next, four of the six principles are discussed in detail, namely (1) providing a clear commander's intent, (2) using mission orders, (3) creating shared understanding, and (4) building cohesive teams through mutual trust. The paper is concluded with a reflection on the connectivity of the discussed principles and their current relevance for successful military leadership.
\end{abstract}

Keywords: Gallipoli Campaign, leadership, mission command principles, Mustafa Kemal, World War I

\section{Introduction}

One of the basic foundations of land operations is the mission command philosophy. This philosophy is considered to be the way to successful command and as the key to win the battle. According to the Military Army Doctrine mission command is:

the exercise of authority and direction by the commander using mission orders to enable disciplined initiative within the commander's intent to empower agile and adaptive leaders in the conduct of unified land operations. [1]

First of all, it should be emphasized that "military operations are complex, human endeavors characterized by the continuous, mutual give and take, moves, and countermoves among all participants" [1]. In order to reach success, commanders have to use mission command principles during the operations. These principles help commanders to conduct a battle and create a good atmosphere in the unit. In the U.S. Army, six principles of mission command exist:

1. Build cohesive teams through mutual trust.

2. Create shared understanding.

3. Provide a clear commander's intent.

4. Exercise disciplined initiative.

*Corresponding author

Email address: blackbest8061@gmail.com (Meu-Chun Wang)
5. Use mission orders.

6. Accept prudent risk.

Nowadays, due to the dynamic situation in the war field, the mission command principles are very important to implement into real life. That is the reason why new unit leaders should know how to use the principles mentioned above. What is more, they should have knowledge about previous battles and ways of used mission command principles in historical battles. Lessons learned from previous battles may help new commanders to improve their leadership skills. This paper will analyze Mustafa Kemal's mission command characteristics with four of the six mission command principles (providing a clear commander's intent; use mission orders; creating shared understanding; and build cohesive teams through mutual trust). The author conducted the analysis of the Gallipoli Battle and ways of command through the prism of the mission command principles.

\section{The Gallipoli Campaign Overview}

The Gallipoli Campaign, also known as the Dardanelles Campaign, the Battle of Gallipoli, or the Battle of Çanakkale was a campaign of the First World War that took place in the Gallipoli peninsula (Gelibolu in modern Turkey). The Ottoman Empire had entered World War I on the side of the Central Powers in November 1914. After few months the first attack on the Dardanelles began when Anglo-French 


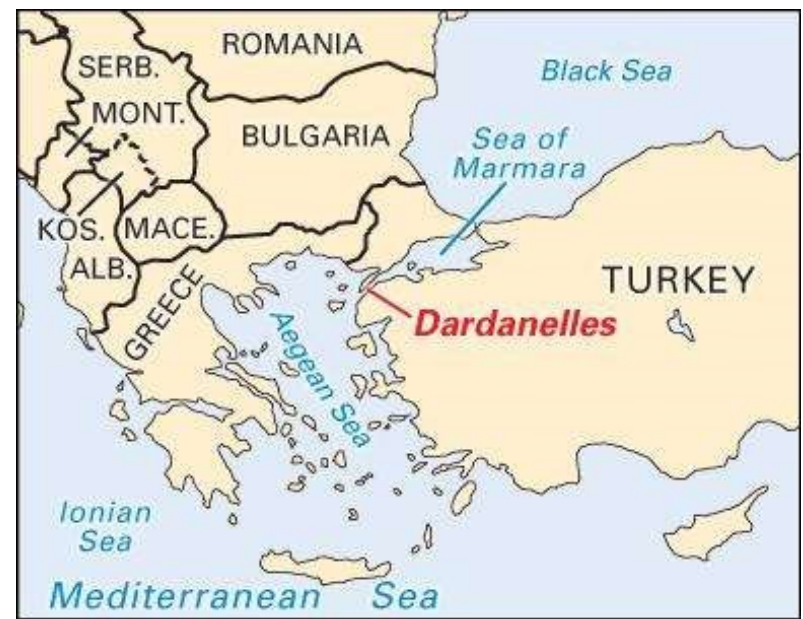

Figure 1: The Gallipoli Campaign area (source: www.britannica.com access: 01/13/2018.

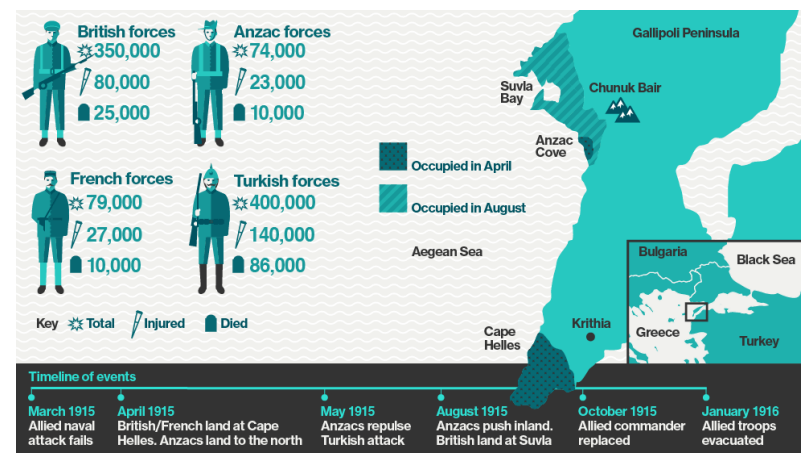

Figure 2: The general timeline and firepower during Gallipoli campaign [2]

task force, including the British battleship HMS Queen Elizabeth, began a long-range bombardment of ottoman coastal artillery batteries. It took place in the Gallipoli peninsula in the Ottoman Empire between February $19^{\text {th }}, 1915$ and January $9^{\text {th }} 1916$. The peninsula forms the northern bank of the Dardanelles, a strait that provides a sea route to the Russia Empire, one of the allied powers during the war.

This campaign was one of the biggest battles during that time due to the numbers of soldiers participated - almost 1 million soldiers from both sides. The general timeline and firepower is presented in the Figure 2.

Intent to secure it, Russia's allies, Britain and France, launched a naval assault followed by an amphibious landing on the peninsula, with the goal of capturing the Ottoman capital of Constantinople. Meanwhile, Mustafa Kemal was the significant Turkish commander during the Gallipoli campaign. His extraordinary performance of mission command supported his leadership of the Turkish National Movement. Under his command, the sick man of Europe, the Ottoman Empire, was transformed into the Republic of Turkey.

\section{Providing a Clear Commander's Intent}

An appropriate commander's intent should clearly and precisely express the purpose and the desired end state for an

\section{The Golden Circle}

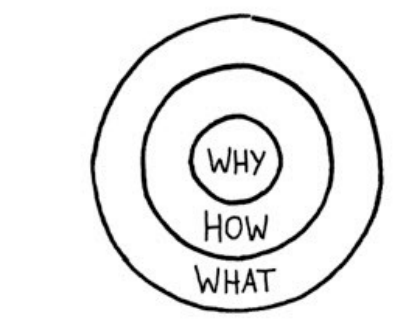

What

Every organization on the planet knows WHAT they do. These are products they sell or the services they offer.

How

Some organizations

know How they do it. These

are the things that make

them special or set them

apart from their competition.

Why

Very few organizations know WHY they do what they do. WHY is no about making money. That's a result. It's a purpose, cause or belief. It's the very reason your organization exists.

Figure 3: The golden circle [5]

operation. In the Army Doctrine Reference Publication 6-0, the clear commander's intent is defined as:

The commander's intent is a clear and concise expression of the purpose of the operation and the desired military end state that supports mission command, provides focus to the staff, and helps subordinate and supporting commanders act to achieve the commander's desired results without further orders, even when the operation does not unfold as planned. [3]

According to the Simon Sinek's Golden Circle Theory, a leader should provide a "why" rather than a "what" to his or her unit, its leaders, people, and constituent parts. [4]

Without a strong reason, it is difficult to persist in fighting during the torture moment. Providing this sounds easy; however, it is not. Demonstrating a commander's intent is a difficult part of mission command to master - it is a form of art built by experience and reflection. An additional challenge is delivering a clear commander's intent to all levels and ensuring that it is universally understood, thus facilitating the seizure of the initiative. On April $25^{\text {th }}, 1915$, the landing of Gaba Tepe was unopposed and inordinately successful allowing the 1st Battalion, King's Own Scottish Borderers, under Lieutenant-Colonel A.S. Koe and the Plymouth Battalion of the Royal Marine Light infantry under Lieutenant-Colonel G.E. Matthews to push almost into the village of Krithia. The Ottoman Army's General Otto Liman von Sanders' (German General leading the Ottoman Army in the Gallipoli battle) order placed less emphasis on defense at the water's edge and explicitly noted that the tactical battle would be won or lost through the launching of decisive concentrated counterattacks within the first 48 hours. In order to secure Gaba Tape, Mustafa Kemal lead his $57^{\text {th }}$ regiment to coordinate with $27^{\text {th }}$ regiment. One of the most impressive words that Mustafa Kemal said to his soldiers during this operation is that "I do not order you to fight. I order you to die." Furthermore, he says "when you are fighting to die this will engage the enemy and during this time the new units will come to support our counter attack". It is a mission order literally, but 
the implied meaning is his intent. He urged his soldiers to fight without fear and to fight with anything what can use. As a commander, to secure this place, his intent is clearly expressed and also inspiring. His regiments defended until the last minute and successfully waited until two reinforcements regiments arrived on April $27^{\text {th }}$. The ever-aggressive Kemal used both fresh regiments to launch coordinated night attacks on the ANZAC's left and center position. They successfully turned back the adversaries. Judging from the mission command principle: to provide a clear commander's intent, Mustafa Kemal had a good demonstration in this counterattack. During the warfare, the commander's clear intent is most important. Unlike General Matthews, who had issued no order throughout the day. Matthews' unclear intent led to undisciplined of the units, which also provided Ottoman Army the chance to counter-attack.

\section{Using Mission Order}

Compared with an intent, a mission order is more detailed and specific. However, an appropriate mission order should be tied to an intent and express it adequately. The effectiveness of a mission order technique has stood the test of time. In 1939, FM 100-5 explained mission orders succinctly:

An order should not trespass upon the province of a subordinate. It should contain everything that the subordinate must know to carry out his mission, but nothing more... Above all, it must be adapted to the circumstances under which it will be received and executed. [6]

Besides, the balance between a clear vision and enough detail is the art of using a mission order. As General George S. Patton, Jr., said, "Don't tell people how to do things, tell them what to do and let them surprise you with the results" [7]. During the counter-attack of Sulva Bay landing, Mustafa Kemal was newly appointed as the Anafarta Group commander. He travelled to the headquarters of the $8^{\text {th }} \mathrm{Di}$ vision at Chunuk Bair with his aid-de-camp and went forward to conduct a personnel reconnaissance and to survey the condition of the men in the forward positions. He determined that the conditions for a multi-divisional counter-attack were favorable due to the presence of relatively fresh Ottoman troops. He started to make preparations for an attack. He ordered the $8^{\text {th }}$ Division to make the main attack and $9^{\text {th }}$ Division was ordered to conduct a supporting attack. The tireless Kemal worked through the night to coordinate the counter- attack and ordered the $7^{\text {th }}$ and $12^{\text {th }}$ Divisions to support with an advance as well. Unlike the Allied force, whose attack was poorly planned without a reconnaissance or rehearsals. Moreover, the maps were inaccurate and the officer had no idea of exactly where the enemy positions were located. Therefore, the surprised British soldiers died in large numbers and some units were entirely eliminated. The Ottomans managed to push the New Zealand Brigade and the $38^{\text {th }}$ Brigade back about 550 yards.

The $39^{\text {th }}$ Brigade withdrew 1100 yards, thus ending the threat to Sari Bair Ridge. As the Anafarta Group commander,

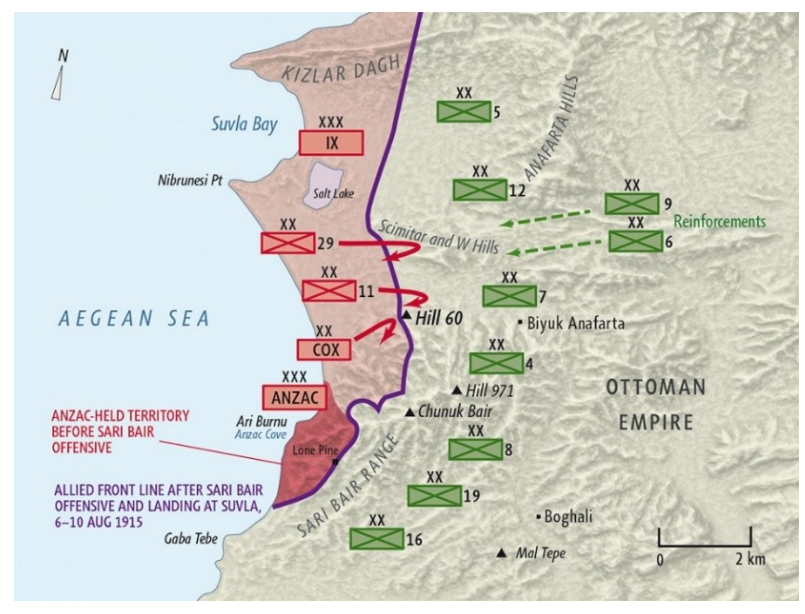

Figure 4: The battle map within withdrew during Gallipoli Campaign. [8]

Mustafa Kemal fully understood the operation picture which made his mission order more suitable for the counter-attack. Then, he did not give his division too many detail order to deploy. He gave his subordinates the chance to manage their own troops by given them general intent. His mission order was mostly a guidance of the function of each division. On the other hand, he conducted a reconnaissance by himself in order to provide enough detailed information for his subordinates. His clear use of the mission order contributed to the victory of this campaign.

\section{Creating Shared Understanding}

Shared understanding requires commanders and staff to engage in continual collaboration as they employ forces in a congested and contested operational environment. What is more, in the U.S. Army Reference Doctrine, this principle is considered as a critical challenge for commanders. Furthermore, ADPR 6-0 explains how to reach this:

\section{Commanders and staffs actively build and maintain shared understanding within the force and with unified action partners by continual collaboration throughout the operations pro- cess (planning, preparation, execution, and as- sessment). [3]}

Shared understanding should be not only created between a commander and his subordinates, but also between units. As a warfare situation shifts rapidly, the more integrated understanding the commander gets, the commander can make a more precise decision.

During the Gallipoli Campaign, Mustafa Kemal conducted numerous of combined operations. On April 25 th, 1915 , the most important decisions were made by the $9^{\text {th }}$ Division commander, Halil Sami, and the $19^{\text {th }}$ Division commander, Mustafa Kemal.

The first Ottoman commander who was in a position to influence the outcome of the landing was Halil Sami, whose division sector included both Anzac and Cape Helles. He ordered his $27^{\text {th }}$ Infantry Regiment to execute a counter-attack 
on the Anzac landing. At the same time, Mustafa Kemal marched his $57^{\text {th }}$ Regiment toward the Third Ridge. There were two Ottoman regiments from different divisions moving to attack the ANZAC. Halil Sami recognized this fact and ordered the $27^{\text {th }}$ Regiment commander Lieutenant Colonel Sefik to coordinate his attack with Kemal. Kemal and Sefik had agreed to a coordinated counter-attack supported by artillery. The result of these attacks was that Australian advance stopped and the division and the other brigade commanders assumed a defensive position. In this case, if they did not cooperate together, they might have wasted their efforts on probably the same actions. Although this campaign was a cross-regiment attack, Kemal and Sefik combined their forces together smoothly and quickly. They established a common understanding of the tactical picture in the war field and their capabilities of their own force which lead to success of the counter- attack. Also, during the counterattack of Sulva Bay landing on August $9^{\text {th }}, 1915$, Mustafa Kemal as the Anafarta Group commander helped rebuild and supply the $8^{\text {th }}$ Division after heavy losses causing a withdrawal. What is more, in order to build up shared understanding between each other, he even traveled to Chunuk Bair, where the headquarters of the $8^{\text {th }}$ Division was located. [9]. After battles in August he expressed a great personal satisfaction [10].

\section{Building Cohesive Teams Through Mutual Trust}

Last but not the least, cohesive teams are built through mutual trust. Mutual trust is confidence between partners and between commanders and their subordinates. Though mission command speaks to the commander and his role in the execution of military operations, a platoon leader can utilize the principles just as effectively. It is critical that the team not only trains and develops a shared confidence between the leaders, but also that it focusses time on training and developing confidence among their subordinates acting in positions above their own. It will enhance the subordinates' understanding of their leaders' positions, and will better prepare the team for unpredictable loss or changes. Staring with the Turkish commanders, the Turkish command was very much dominated by Liman von Sanders and Mustafa Kamel. Liman von Sanders became the inspector of the Turkish Army and was given command of the Turkish forces in the Caucasus upon the outbreak of war, but in March 1915 he was transferred to command the $5^{\text {th }}$ Army on the Gallipoli peninsula. His relationship with his subordinates was decisive. He had no hesitation in dismissing Fevzi Bey at the start of the Sulva operation, and gave the chance to Mustafa Kemal, which his talents justified. However, his relationship with his superior, Enver Pasha, was poor. Enver Pasha had a poor grasp of military affairs in spite of his high rank. He had some active service in the Italo- Turkish War, but the operations he conducted were marked by a conspicuous lack of success. [9]

Enver's relations with his subordinates seem to typify the jealousy and lack of co-operation which afflicted the entire
Turkish command. Kemal's abilities were submerged by Enver's rise, and conflict between the two was inevitable. Compared with Enver's lack of military knowledge, Kemal had a superb grasp of strategy and an ability to inspire troops. As a result, of the difficulty between Enver and Kemal, it was difficult to build mutual trust with his superiors. Due to the poor relation with his superior, Mustafa Kemal's mission command was not able to perfectly fit this principle. However, he took advantage of his excellence at understanding situations and the ability to inspire his troops by his reckless bravery in action which made up for his deficiency and built up mutual trust with his troops.

\section{Conclusion}

The Gallipoli Campaign lasted for eight months and gained up to 390000 casualties on both sides [11]. The only major victory of the war is Ottoman Empire. It was a significance moment for Turkish national history. It was final surge in the defense of the motherland as the Ottoman Empire crumbled. The struggle formed the basis for the Turkish War of Independence and the declaration of the Republic of Turkey eight years later, with Mustafa Kemal as President, who rose to prominence as a commander at Gallipoli. In the Gallipoli Campaign, there are four significant parts of my analysis. First, the mission order is strongly related to commander's intent. All of the actions and orders referred to the campaign originate from the commander's intent. If the commander has a clear intent, it will be easier to make effective orders. Moreover, using a mission order can give subordinates the chance to demonstrate their ideas and give commanders more time to deal with other affairs. Sometimes, subordinates' ideas are useful. Secondly, creating shared information is important to integrate multi units. The principle to create shared understanding is obviously important.

Even in the $21^{\text {st }}$ century, countries continue to develop the integrated military systems in order to establish a joint force. Mustafa Kemal was excellent at commanding different units. No matter which regiments or forces he was going to cooperate with, he always created the shared understanding with his friendly units initiatively.

Thirdly, situation understanding is a key factor of the commander's intent and order. Situation understanding is not one of the six mission command principles in the U.S. Army. However, soldiers always follow the one who give them correct direction. Having good ability for situation understanding can generate more correct decision for the operation. It also helps to build up mutual trust. If the commander is poor at grasping strategy, no matter how clear an intent he has and how decisive the order he uses, they are all in vain. Finally, the commander's wisdom is most important. It is difficult for a commander to fit every mission command principle. The operation picture shifts every second. A commander cannot estimate and control everything in the warfare. As a result, a commander needs to use his/her wisdom to overcome obstacles. it serves as guidance for successful mission command. It will be useful for our future military career. 


\section{References}

[1] Departament of the Army., ADRP 6-0 Mission Command., Washington D.C.: Government Printing Office. (2014).

[2] J. Torode, BBC, Retrieved from (2017). [link]. URL http: //www . bbc.co.uk/guides/zy j4kqt

[3] Departament of the Army., ADP 6-0 Mission Command., Washington D.C.: Government Printing Office. (2012).

[4] S. Sinek (Director)., Start with why - how great leaders inspire action [Motion Picture] (2009).

[5] smartinsight, Retrieved from The golden circle (August 19, 2017).

URL https://www.smartinsights.com/digital-marketingstrategy/online-value-proposition/start-with-whycreating-a-value-proposition-with-the-golden-circlemodel/

[6] Departament of the Army., M 100-5, Tentative Field Service Regulations, Washington D.C.: Government Printing Office. (1939).

[7] N. K. Finney, Retrieved from (2016). [link].

URL http://armypress.dodlive.mil/files/2016/04/missioncommand-in-the-21st-century $\cdot$ pdf .

[8] Conspiracy-cafe, Retrieved from The gallipoli campaign (August 20 2017).

URL http://www.conspiracy-cafe.com/apps/blog/show/ 43265267-the-gallipoli-campaign

[9] E. J. Erickson, Gallipoli Command Under Fire., New York: Osprey (2015).

[10] M. M. Iskora, Turk Ordus Kurmaylik (Erkaniharbiye) Tarihcesi., Harb Akademesi Matbaasi. (1944).

[11] New Zealand History., Retrieved from Gallipoli casualties by country (August 12, 2017).

URL https://nzhistory.govt.nz/media/interactive/ gallipoli-casualties-country

[12] Link 16 (2006).

URL https://en.wikipedia.org/wiki/Link_16 